IZA DP No. 8285

Corporate Efficiency, Credit Status and Investment

Manzur Quader

Karl Taylor

June 2014

Forschungsinstitut

zur Zukunft der Arbeit

Institute for the Study

of Labor 


\title{
Corporate Efficiency, Credit Status and Investment
}

\author{
Manzur Quader \\ Chittagong Independent University \\ Karl Taylor \\ University of Sheffield \\ and IZA
}
Discussion Paper No. 8285
June 2014

IZA
P.O. Box 7240
53072 Bonn
Germany

Phone: +49-228-3894-0

Fax: +49-228-3894-180

E-mail: iza@iza.org

Any opinions expressed here are those of the author(s) and not those of IZA. Research published in this series may include views on policy, but the institute itself takes no institutional policy positions. The IZA research network is committed to the IZA Guiding Principles of Research Integrity.

The Institute for the Study of Labor (IZA) in Bonn is a local and virtual international research center and a place of communication between science, politics and business. IZA is an independent nonprofit organization supported by Deutsche Post Foundation. The center is associated with the University of Bonn and offers a stimulating research environment through its international network, workshops and conferences, data service, project support, research visits and doctoral program. IZA engages in (i) original and internationally competitive research in all fields of labor economics, (ii) development of policy concepts, and (iii) dissemination of research results and concepts to the interested public.

IZA Discussion Papers often represent preliminary work and are circulated to encourage discussion. Citation of such a paper should account for its provisional character. A revised version may be available directly from the author. 
IZA Discussion Paper No. 8285

June 2014

\section{ABSTRACT \\ Corporate Efficiency, Credit Status and Investment}

Using a panel of 1122 UK firms listed on the London Stock Exchange over the period of 1981 to 2009, endogenous switching regression models (SRM) incorporating a predicted corporate efficiency index are estimated in this paper in an effort to clarify the role of cash flow in examining the impact of capital-market imperfections. It is revealed that a firm's constrained credit status changes with the improvement of its efficiency. The results further reveal that financially constrained firm's investment is comparatively more sensitive to cash flow, but this sensitivity is negatively and significantly related with corporate efficiency. These results point to the fact that high investment sensitivity to cash flow may not be solely driven by measurement error in investment opportunity, but may still be interpreted as a consequence of imperfect substitutability between internal and external financing arising from the capital market imperfections.

JEL Classification: C34, D92, G14, L21

Keywords: asymmetric information, financial constraints, switching regression

Corresponding author:

Manzur Quader

School of Business

Chittagong Independent University

16, Jamal Khan

Chittagong

Bangladesh

E-mail: manzur@ciu.edu.bd 


\section{Introduction}

Informational asymmetries and related problems, i.e., imperfect information about the quality or riskiness of the borrowers' investment projects, incentive problems and costly monitoring of managerial actions lead to an imperfect substitutability between external and internal funds and makes the Modigliani and Miller (1958) irrelevance theorem invalid. Bernanke and Gertler (1989), Calomiris and Hubbard (1990), Gertler (1992), Kiyotaki and Moore (1997), Greenwald and Stiglitz (1993) and Schiantarelli (1996) discuss a variety of methodological issues and provide econometric evidence on the consequences of these problems on the investment behavior of firms. These models emphasize the costs of adverse selection and moral hazard in generating frictions in the capital markets. The conclusions drawn in these literatures are twofold. Firstly, the effective cost of external financing becomes higher than that of the internal finance unless the loans are fully collateralized and secondly, the premium on such external financing is inversely related to a firm's net worth. The underlying reason for this inverse relationship is that the potential conflict of interests between borrowers and suppliers of external funds is greater when borrowers do not have sufficient funds to contribute to project financing and whenever there occurs a negative shock to a firm's net worth, these conflicts deteriorate further. Therefore, lenders must be compensated with a premium for the risk that borrowers may either misrepresent the quality of a given investment project or behave in a manner that expropriates value from lenders. In general, such risk premium increases with the severity of information asymmetries or difficulty in mitigating the opportunistic behavior (Gilchrist and Zakrajsek, 1995). With a higher premium and hurdled access to external financing this compels firms to rely more on internal financing sources and results in higher sensitivity of investment to their availability. Hubbard (1998) presents an excellent graphical illustration of these arguments.

The debate on whether this high sensitivity of investment to internal financing can be interpreted as an indicator of financial constraints started with Fazzari, Hubbard, Petersen, Blinder, and Poterba (1988) and Kaplan and Zingales (1997) who hold completely different views in terms of classifying firms as financially constrained or not and also their investment responsiveness to cash flow. Fazzari et al. (1988) propose the monotonicity hypothesis according to which the sensitivity of investment to cash flow should increase with the severity 
of market imperfection. In contrast, Kaplan and Zingales (1997) report that the sensitivity of investment to cash flows is non-monotonic with respect to financial constraints. More recently, Moyen (2004) argues that it is hard to identify firms with financial constraints and finds evidence in support of both Fazzari et al. (1988) and Kaplan and Zingales (1997) using two different unconstrained and constrained firm models. Cleary, Povel, and Raith (2007) try to explain this contrasting behavior by showing that the relationship between the firm's internal funds and investment is not monotonic, but U-shaped. Lyandres (2007) complements this U-shaped relationship by examining the effects of costly external financing on the optimal timing of a firm's investment and Guariglia (2008) finds varying investment cash flow sensitivity for internally and externally financial constrained firms. Therefore, it is quite evident from the literature that investment cash flow sensitivity critically depends on the classification criteria or procedure used and this has been considered as one of the reasons for the conflicting findings in the existing literature. A vast number of literatures follow this debate and the controversy is yet to be resolved. Schiantarelli (1996), Hubbard (1998), Lensink, Bo, and Sterken (2001), Bond and Van Reenen (2007) provide ample support for this implication.

For more than two decades, this debate over the role of cash flow in an investment equation has been centered mainly on two crucial points. The first of them stems from the difficulty in controlling for the investment opportunities of a firm. Most studies use average $\mathrm{Q}$ under the assumption of constant returns to scale and perfectly competitive product and factor markets following Hayashi (1982) and adding cash flow to the model, they interpret residual sensitivity of investment to cash flow as evidence of financing constraints (Fazzari et al., 1988, Oliner and Rudebusch, 1992, Devereux and Schiantarelli, 1990, Hoshi, Kashyap, and Scharfstein, 1991, Schaller, 1993, Audretsch and Elston, 2002, Bond, Elston, Mairesse, and Mulkay, 2003, Chirinko and Schaller, 1996). On the contrary, Gilchrist and Himmelberg (1995), Erickson and Whited (2000, 2002), Cummins, Hassett, and Oliner (2006) show that because of difficulty in measuring marginal investment opportunities, cash flow may also convey information about investment opportunities which is not reflected in the estimated Q. In such cases, the observed cross-sectional variations in investment-cash flow sensitivity may simply be due to variations in Q measurement error and fails to provide convincing proof for 
the existence of capital market imperfections. Moreover, the firms facing severer information asymmetry related problems are likely to be more severely affected by the measurement problem in $\mathrm{Q}$ as that incorporates firm market value. These firms are also the ones which are most likely to be financially constrained and if they are a priori classified as such, higher estimated coefficients of cash flow in investment regressions is expected for them.

Such prior classification of firms into constrained and unconstrained groups is the other crucial point behind the controversial investment cash flow sensitivity issue. Following Fazzari et al. (1988), many subsequent studies have classified firms a priori as financially constrained on the basis of a single and in some cases two quantitative or qualitative indicators and the predictive power of cash flow is shown to be much higher for such firms. The major concern in this technique is the endogenous selection problem as the classification criteria can be correlated with the level of investment or with the firm-specific and time invariant component of the error term and also with the idiosyncratic component (Hausman and Wise, 1977). The estimation results thus can be highly sensitive to the classification criteria and threshold value chosen for the sample split and all these are likely to cause static misclassification. There are potential problems of dynamic misspecification as well as the exogenously classified firms that are kept in the same regime over the whole sample period discarding the possibility that financial constraint status of a firm may change over time. This will especially be the case when the extent of capital market imperfections depends on the general macroeconomic environment and becomes more important when the time period under consideration lengthens. Hence, although it is possible to identify firms that may be financially constrained, it is quite often impossible to identify the years during which they remain constrained. This makes it almost impossible to differentiate between firm-specific effects on investment and the effects of financing constraints (Kaplan and Zingales, 1997). To tackle the problems mentioned above, we attempt to combine and make use of the following remedial measures in this paper.

Firstly, we concentrate on the changing pattern of investment-cash flow sensitivities with a variable measuring the extent of such imperfection based on the idea that investment-cash flow sensitivity should change with capital market imperfection if it is at all linked with these imperfections. For this, we use the stochastic frontier approach to compute an estimate of 
the corporate efficiency of a firm as an inverse proxy of agency costs by comparing a firm's actual Tobin's Q with its best performing benchmark Q following Habib and Ljungqvist (2005) and Nguyen and Swanson (2009). ${ }^{1}$ We anticipate that the effect of this efficiency on the cash flow sensitivities of investment will be dissimilar between firms with different degrees of financial constraints. More importantly, efficiency can in fact affect the credit status of the firms as a financially constrained firm may become unconstrained with the improvement of its efficiency and a non monotonic effect of corporate efficiency on cash flow sensitivities may be established.

Secondly, we try to endogenously classify firms according to their financial constraint status and allow switching between them to avoid the static and dynamic misclassification problems and in line with our prediction that corporate efficiency can simultaneously affect a firm's financial constraint status and investment cash flow sensitivity. In order to do that, we rely on an endogenous switching regression framework with unknown sample separation which is capable of incorporating the effects of efficiency on cash flow sensitivities and on the constraint status of the firms simultaneously. This model allows determination of firms' probability of facing constrained or unconstrained access to credit as well. Hu and Schiantarelli (1998), Hovakimian and Titman (2006), Almeida and Campello (2007) use such models in their attempt to address the problems in testing for financial constraints.

This paper provides a distinctive complement to the existing literature by introducing corporate efficiency in the investment equation in another attempt to clarify the role of cash flow. Despite the existing concerns over the role of cash flow, we argue that investmentcash flow sensitivities can be used to gauge the effects of financing frictions on investment by trying to resolve the issue of possible biases arising from unobservable variation in investment opportunities. Further to this, the expected non monotonic effect of corporate efficiency on cash flow sensitivities may provide a different resolution to the highly debated Fazzari et al. (1988) and Kaplan and Zingales (1997) issues. Another interesting feature of this study is

\footnotetext{
${ }^{1} \mathrm{~A}$ more detailed explanation and discussion of the properties of this predicted efficiency measure can be found in chapter 2 of Quader (2013). Here, we use the market value efficiency measure calculated from the final model 2 of table 2.2 (p. 51) of the thesis.
} 
its contribution to the debate with a focus on the UK rather than the US. To the best of our knowledge, a switching regression model has not been used in any of the UK studies involving financial constraints and investment.

Using an unbalanced panel data on 1122 UK firms listed on the London Stock Exchange during the period 1981 to 2009, we estimate a number of endogenous switching regression models incorporating our predicted corporate efficiency from the stochastic frontier analysis along with other variables used in contemporary literatures. Our different model specifications strive to confront the major challenges in examining the effects of capital-market imperfections on investment decisions of individual firms and will mainly concentrate on inspecting the following:

1. whether, and how, efficiency affects the likelihood of being financially constrained or unconstrained;

2. whether investment-cash flow sensitivity is increasing or decreasing with efficiency; and

3. whether the effect of efficiency on cash flow sensitivities is monotonic or non-monotonic.

This paper is structured into different sections as follows. Section 2 is a literature survey, section 3 describes the methodology, section 4 brings model specification and description of the variables, section 5 introduces data and descriptive statistics, section 6 presents the empirical results and analysis and finally section 7 concludes the paper.

\section{Literature review}

The controversial role of cash flow in an investment equation remains the main focal point in many of the past and recent literatures on financial constraints and investment. On the whole, the literature on this field of study can be divided into following three themes.

\subsection{Classification of firms into financially more or less constrained groups}

The seminal paper by Fazzari et al. (1988) use US firm-level data to inspect the differences in the sensitivity of investment to cash flow across groups of firms divided according to the degree of financial constraints. They classify low-dividend paying firms as more likely to face financial constraints and the investment level of such firms are found to be relatively 
more affected by the availability of cash flow in comparison with the high-dividend paying unconstrained firms and thus provide useful evidence in favor of the existence of financial constraints under capital market imperfections. The higher sensitivity of investment to cash flow for financially constrained firms has been scrutinized by a number of papers including Kaplan and Zingales (1997). Using information contained in the firms' annual reports and managements' statements on internal liquidity, they classify firms without access to more funds than needed as financially constrained and their investment is likely to be less sensitive to cash flow. This conflicting finding with Fazzari et al. (1988) recommends that higher sensitivities of investment to cash flow may not be sufficiently used as evidence that firms are more financially constrained. The Kaplan and Zingales (1997) classification scheme has been criticised later by Fazzari, Hubbard, and Petersen (2000) in terms of both classification method and degree of financial constraints. Kaplan and Zingales (2000) later claim that the comparative static analysis of Fazzari et al. (2000) are in fact supportive of their earlier conclusions and the criticisms regarding their classification scheme and empirical results are unjustified. Allayannis and Mozumdar (2004) also doubted that the results in Kaplan and Zingales (1997) are mainly caused by the presence of financially distressed firms or outliers in their sample. Most recently, Bond and Söderbom (2013) show that the non-monotonic investment cash flow sensitivity highlighted by Kaplan and Zingales (1997) has little relevance for evaluating this line of research.

The opinions therefore are divided into two subsets and have been supported by their proponents. The deviation arises mainly because of the different ways they use to measure financial constraints, namely external and internal financial constraints (Guariglia, 2008). Proponents of Fazzari et al. (1988) use proxies to measure the extent of external financial constraints faced by the firms. For example, Devereux and Schiantarelli (1990), Gertler and Gilchrist (1994), Oliner and Rudebusch (1992), Kadapakkam, Kumar, and Riddick (1998) and Shin and Kim (2002) use size, age and pattern of insider trading, Hoshi et al. (1991) and Shin and Park (1999) use degree of industrial and bank affiliation, Bond and Meghir (1994) use dividend payout ratio. Alternatively Calomiris, Himmelberg, and Wachtel (1995) use credit rating, Whited (1992) use bond rating, and Schaller (1993) adopt the degree of shareholding concentration. On the other hand, indicators related to the level of internal 
financial constraints faced by the firm have been adopted by the studies supporting Kaplan and Zingales (1997) view. Cleary (1999) constructs an index of firm's financial strength using a number of variables indicating the extent of the internal liquidity of a firm (e.g. the current ratio, financial slack, net income margin, sales growth, debt ratio). Lamont, Polk, and Sa-Requejo (2001) also calculate a multivariate index by weighting five similar variables. Using varying combinations, some other classification indexes of financial constraints have also been developed. The appealing examples of these include the WW index of Whited and Wu (2006), the synthetic index of Musso and Schiavo (2008) and the SA index proposed by Hadlock and Pierce (2010). Aggarwal and Zong (2006) adopt discriminant analysis to estimate a beginning-of-period financial constraint index using the variables used by Cleary (1999) and use that index to classify firms of the four largest industrialized countries (US, UK, Japan and Germany) into three financial constraint categories.

The single or multiple factor classifications applied with the investment regression approach may not successfully separate firms with different levels of investment-cash flow sensitivity and create the static and dynamic misclassification problem as already discussed. $\mathrm{Hu}$ and Schiantarelli (1998) first address the ex ante classification problem using endogenous switching regression methods with unknown sample separation, where the probability of being constrained or unconstrained is determined by a switching function of a vector of firm specific and some other characteristics that proxy for the severity of informational and agency problems. They interpret the varying effect of cash flow on investment across the two groups of US manufacturing firms in terms of imperfect substitutability between different sources of finance and their results provide strong evidence that such effects vary with the severity of agency cost problems. Hovakimian and Titman (2006), Almeida and Campello (2007), Adelegan and Ariyo (2008), Hobdari, Jones, and Mygind (2009) also apply the switching regression technique for their financial constraints analysis.

\subsection{Measurement error in investment opportunities}

The main shortcoming of the Fazzari et al. (1988) methodology arises from the fact that average Q may not be a very precise proxy for the shadow value of an additional unit of new capital and the significance of cash flow may give biased results. Erickson and Whited (2000, 
2002) postulate that such biases induced by measurement error in Q can be substantial and may be responsible for the estimated coefficients on Q being low and those on cash flow being high. They attempt to tackle this problem by using a class of measurement error-consistent GMM estimators that utilize the information in the higher order moments of the data. After including the estimated error adjusted $\mathrm{Q}$ in their model, they find that cash flow turns out to be statistically insignificant even for the financially constrained firms, but Q theory has good explanatory power once the measurement error problem is controlled for. Gomes (2001) and Alti (2003) also provide results against Fazzari et al. (1988) by saying that the significance of cash flow can also occur in the absence of capital market frictions.

Another major blow to the findings of Fazzari et al. (1988) comes from Bond and Cummins (2001), Bond, Klemm, Newton-Smith, Syed, and Vlieghe (2004), and Cummins et al. (2006). They construct more accurate measures of the fundamentals which affect the expected returns on investment by using firm-specific earnings forecasts from securities analysts and Cummins et al. (2006) name it "real Q". Once expected profitability is controlled for by using Institutional Brokers Estimate System (I/B/E/S) analysts' earnings forecasts, the correlation between investment spending and cash flow disappears in all subsamples of firms. Gilchrist and Himmelberg (1995) estimate a set of VAR (vector auto regression) forecasting equations including cash flow as one of the observable fundamentals to construct the expected value of marginal $\mathrm{Q}$ conditional on observed fundamentals and they term it as "Fundamental Q". However, they find that investment still responds to cash flow even after controlling for its role as a forecasting variable for future investment opportunities and suggest that the excess sensitivity of investment to cash flow is not spuriously generated by cash flow's ability to predict future investment opportunities.

Another way to address the measurement error issue is to estimate the Euler equation for the capital stock by avoiding the reliance on Q to measure expected profitability. The goal of this estimation is that the standard Euler equation derived under the assumption of perfect capital markets should be misspecified for the a priori classified financially constrained firms, but not for the unconstrained ones. Whited (1992), Hubbard, Kashyap, and Whited (1995) and $\mathrm{Ng}$ and Schaller (1996) estimate the standard Euler equation and an Euler equation augmented with financial variables for various categories of firms using US data and Bond 
and Meghir (1994) estimate the same using UK data. Their results support that the standard Euler equation generally holds only for firms less likely to face financial constraints. The problem in this estimation technique is that it may not be able to detect the presence of financial constraints if the severity of such constraints remains roughly constant over time.

Bond et al. (2003) employ both an error correction model and an Euler-equation specification for estimating their investment equations using panel data sets for manufacturing firms in four European countries, Belgium, France, Germany, and the United Kingdom, covering the period 1978-1989 to investigate the role played by financial factors in each country. They find that financial variables like cash flow and profit terms appear to be both statistically and quantitatively more significant in the UK and its financial system performs less well in channeling investment funds to firms with profitable investment opportunities compared to the other three continental European countries. This is consistent with the suggestion that financial constraints on investment may be more severe in the relatively market-oriented UK financial system.

\subsection{Alternative ways to verify the performance of the cash flow sensitivity of investment}

Agca and Mozumdar (2008) emphasize that if investment-cash flow sensitivity is linked with capital market imperfections, then it should decrease with factors that reduce these imperfections. Applying Erickson-Whited error correction estimations to US manufacturing firm data, they find that investment-cash flow sensitivity of these firms decreases with increasing fund flows, institutional ownership, analyst following, antitakeover amendments and with the existence of a bond rating. Therefore, they conclude that the sensitivity of investments to the availability of internal funds cannot be interpreted solely as an artefact of measurement error. Inspired by the above findings, Attig, Cleary, El Ghoul, and Guedhami (2012) empirically investigate the relationship between institutional investor's investment horizon and investment cash flow sensitivity using US firm level data as well. They argue that the presence of institutional investors with a long-term investment horizon provides improved corporate governance by enhancing the effectiveness of their monitoring and hence mitigates asymmetric information and agency conflict between shareholders and managers. This in turn reduces the wedge between the costs of internal and external funds and as a 
result, the sensitivity of firms' investment spending to internal cash flows decreases. So they augment the standard investment regression with an interaction term between cash flow and various proxies for institutional investors' investment horizon (IIIH) and provide evidence consistent with these arguments.

Ascioglu, Hegde, and McDermott (2008) also find higher investment-cash flow sensitivity for firms with high information asymmetry, but they use the probability of informed trade (PIN) to classify firms as constrained which is a more direct measure of financial constraint. They claim that financial constraints matter only at high levels of informational frictions and their results are robust to other alternative specifications that control for different time periods, firm size, debt capacity, and probable measurement error of Q. Bond and Söderbom (2013) study the sensitivity of investment to the availability of internal finance conditional on measures of Tobin's Q in a benchmark model with quadratic adjustment costs and show that the relationship between the investment cash flow sensitivity and capital market imperfection is monotonic. For firms in a financially constrained regime, they find that the sensitivity of investment to cash flow increases monotonically with the cost premium for external finance when they consider equity as the only source external finance. The result remains same when they introduce costly debt as an additional source of external finance. By generating simulated panel datasets for samples with 2000 firms observed for 14 periods at the same time, they find a similar monotonic relationship between the estimates of conditional investment cash flow sensitivity and the cost premium parameters for both sources of external finance.

Carpenter and Guariglia (2008) use UK firms' contracted capital expenditure to capture information about opportunities available only to insiders and thus not included in Q. ${ }^{2}$ When they include this as regressor along with $\mathrm{Q}$ and cash flow in their investment equation to assess the overall investment opportunities of the firm more comprehensively, the explanatory power of cash flow falls for large firms, but still plays a significant role on the small firms' investment. They explain this as evidence that cash flow may still play its role in capturing

\footnotetext{
${ }^{2}$ The contracted capital expenditure variable reflects the insiders' evaluation of investment opportunities and it is defined as contracts entered into for the future purchase of capital items, expenditure on machinery, equipment, plant, vehicles, and buildings, for which nothing has been paid by balance sheet date.
} 
the effects of capital market imperfections, at least for the small firms which are more likely to be financially constrained as well. In another paper using UK data, Guariglia (2008) finds that the sensitivity of investment to cash flow responds differently according to the type of constraint. The resulting relationship between investment and cash flow is $\mathrm{U}$ shaped when the sample is divided on the basis of internal financial constraints and monotonically increasing with the degree of external financial constraints faced by firms. By combining both types of constraints, she finds that the sensitivity is particularly large when external constraints are strong and internal constraints are weak. These results suggest that the controversy about whether higher investment cash flow sensitivity can be used as evidence of financial constraints is probably due to different sample separation criteria and may not necessarily be due to the improper measurement of $\mathrm{Q}$.

A switching regression framework is employed by $\mathrm{Hu}$ and Schiantarelli (1998) in order to address the problem of cash flow's controversial role by allowing the coefficient on cash flow to differ from zero in the low premium or unconstrained regime. Therefore, even if cash flow contains some information about future profitability, the estimated cash flow coefficient for the constrained firms will be relatively higher than that of the unconstrained firms. Whereas, Hovakimian and Titman (2006) claim that their estimated sensitivity of investment expenditures to asset sales is less affected by the measurement error in their proxy for investment opportunities as it is not likely to be positively related to asset sales. Their switching regression results reveal that after controlling for investment opportunities and cash flows, cash from asset sales is a significant determinant of corporate investment expenditures and financially constrained firms are likely to invest more when they generate cash from asset sales, but this relationship is invalidated for financially unconstrained firms, all listed on NYSE, AMEX and NASDAQ. Exploring the idea that the financial constraint status is endogenously related to the tangibility of the firm's assets, Almeida and Campello (2007) show that investment-cash flow sensitivity for the constrained firms increases with the tangibility of their assets, but not so for unconstrained firms using the universe of manufacturing firms available from COMPUSTAT. Moreover, their switching regression results also show that asset tangibility affects the credit status of the firms and the investment-cash flow sensitivities are not monotonically related to the degree of financing constraints. This 
paper follows the model of Almeida and Campello (2007), but will use predicted corporate efficiency from the stochastic frontier analysis in addition to asset tangibility assuming that financial constraint status can be endogenously related to the efficiency as well.

\section{Methodology}

The main advantage of the switching regression approach is that the extent of investment behavior differing across groups of firms and the set of multiple characteristics determining their likelihood of being financially constrained or unconstrained can be determined simultaneously. The single-factor classifications discussed earlier may not successfully separate firms with different sensitivity of investment to internal financing. The severity of financial constraints can even vary among firms of the same subgroup if other factors are not controlled for. On the other hand, multiple factor classifications increase the number of subsamples reducing the size of each group used for estimation or increase the number of interactive terms in single regressions and produce imprecise estimates. The switching regression approach controls for multiple indicators that jointly determine the group in which a firm is likely to belong without the need for splitting the sample into many smaller parts or including many interaction terms and also allows assessing their statistical significance. Furthermore, the selection regression incorporates more information into the estimation of the separate investment regimes than can possibly be captured by the creation of dummy variables or sample splits.

In the switching regression model, it is assumed that there are two different investment regimes, regime 1 and regime 2. While the number of investment regimes are taken as given, the points of structural change are not observable and are estimated together with the investment equation for each one of the regimes. Depending on the extent of financial constraints, a firm may operate in one of the two unobservable investment regimes and its investment may be more or less sensitive to the availability of internal funds than in the other. The model is composed of the following system of three equations that are estimated 
simultaneously:

$$
\begin{array}{r}
I_{1 i t}=X_{i t} \beta_{1}+\nu_{1 i t} \\
I_{2 i t}=X_{i t} \beta_{2}+\nu_{2 i t} \\
y_{i t}^{*}=Z_{i t} \alpha+\epsilon_{i t}
\end{array}
$$

Equations 1 and 2 are the structural equations that describe the investment behavior of firms in the alternative regimes. Equation 3 is the selection equation that determines a firm's propensity of being in one or the other investment regime. $X_{i t}$ are the determinants of corporate investment and $Z_{i t}$ are the determinants of a firm's likelihood of being in the first or the second investment regime at time t. $\beta_{1}, \beta_{2}$ and $\alpha$ are vectors of parameters and $\nu_{1}, \nu_{2}$ and $\epsilon$ are residuals. The observed investment, $I_{i t}$, undertaken by firm i at time t, is defined as follows:

$$
\begin{aligned}
& I_{i t}=I_{1 i t}, \text { if } y_{i t}^{*}<0 \\
& I_{i t}=I_{2 i t}, \text { if } y_{i t}^{*} \geq 0
\end{aligned}
$$

$y_{i t}^{*}$ is a latent variable measuring the tendency or the likelihood of being in the first or second regime. Firms will not be fixed in one regime, as described in equation (4-5), a transfer between the regimes occurs if $y_{i t}^{*}$ reaches a certain unobservable threshold value. It is assumed that the vector of error terms in the investment and switching functions $\left(\nu_{1 i t}, \nu_{2 i t}, \epsilon_{i t}\right)^{\prime}$ is jointly normally independently distributed with mean zero and covariance matrix $\sum$, which allows a non-zero correlation between the shocks to investment and the shocks to firms' characteristics and endogenous switching between the two investment regimes, where

$$
\sum=\left(\begin{array}{ccc}
\sigma_{1}^{2} & \sigma_{12} & \sigma_{1 \epsilon} \\
\sigma_{21} & \sigma_{2}^{2} & \sigma_{2 \epsilon} \\
\sigma_{\epsilon 1} & \sigma_{\epsilon 2} & 1
\end{array}\right)
$$

Here, $\operatorname{var}(\epsilon)$ is normalized to 1 as only $\alpha / \sigma_{\epsilon}$ can be estimated in equation 3 , but not $\alpha$ and $\sigma_{\epsilon}$ individually (Hovakimian and Titman, 2006). The extent to which investment spending differs across the two regimes and the likelihood that firms are assigned to either regime are simultaneously determined. This approach yields separate regime-specific estimates for investment equations, dispensing with the need to use ex ante regime sorting. In order to fully identify the switching regression model, it is needed to determine which regime is the 
constrained and which regime is the unconstrained. The algorithm specified in equations (1-5) creates two groups of firms that differ according to their investment behavior. The theoretical priors about which firm characteristics and how they are associated with financial constraints are used to achieve this identification.

The dependent variables in the two regime specific equations (1) and (2) are investment and the dependent variable in the classification equation (3) is a classification variable. An initial guess of the classification variable is created using the corporate efficiency index we have estimated by the stochastic frontier analysis (Quader, 2013) based on the assumption that highly efficient firms or firms suffering less from agency cost related problems are most likely be financially unconstrained. For example, the observations are coded as 1 (unconstrained) if their predicted efficiencies are above the 50th percentile value and 0 (constrained) otherwise. However, as the predicted market value efficiency is skewed (figure 1), we also change the initial cut off point to 60 th, 70 th or 80 th percentile values to check the sensitivity in the estimations. Since the estimated probabilities of observations belonging to any of the regimes are not generally just zero or one, the elements of the classification vector will fall throughout the interval $[0,1]$. [Fig 1 will be inserted here]

\section{Model Specification}

\subsection{Investment equation}

The Q-theory of investment proposes that the ratio of the market value of capital stock to its replacement cost could summarize investment opportunities and thus offers another formulation of the neoclassical model (Tobin, 1969). This is later extended to models of investment by Hayashi (1982), who claim that average Q can adequately capture investment opportunities and explain investment demand under the assumption of perfect competition, constant returns, capital as the only quasifixed factor and convex costs of adjusting the capital stock. These models are later augmented by financial variables to examine the effects of capital market imperfections contemplating that firms with higher net worth should invest more for given levels of investment opportunities, information costs, and market interest rates under the deviated market condition. In this paper, we rely on the extended Q theory of investment model to identify the difference in investment behavior across groups of firms 
in our switching regression framework. The variables that measure liquidity, predicted corporate efficiency, asset tangibility, interaction terms of efficiency and tangibility with cash flow are added to the basic reduced form equation of investment to form the $X_{i t}$ vector of equations 1 and 2. Rather than including firm dummies for each of the 1122 firms, we include sector dummies based on the assumption that firm characteristics will be similar within each of the 33 sectors classified by the FTSE/Dow Jones Industrial Classification Benchmark (ICB) codes. Year dummies are also included to capture year specific effects.

We estimate two different models in line with the existing literature and our propositions. As explained earlier, each of these models will have two identically specified investment equations and one different selection equation. In model $\mathbf{1}$, we include efficiency and its interaction term with cash flow in the investment equations to check the magnitude and direction of investment-cash flow sensitivity and its changing pattern with corporate efficiency across endogenously classified group of firms.

$$
\begin{aligned}
& I_{i t}=\beta_{0}+\beta_{1} \text { Cash flow } \text { flt }+\beta_{2}(\text { Cash flow } \times \text { Efficiency })_{i t}+\beta_{3} \text { Fin. slack } \text { St }_{i t} \\
& +\beta_{4} \text { Tobin's }^{\prime} Q_{i t}+\beta_{5} \text { Efficiency }{ }_{i t}+f_{i}+\tau_{t}+\nu_{i t}
\end{aligned}
$$

In model 2, we additionally include asset tangibility and its interaction with cash flow in the investment equations in a similar attempt to check the changing pattern of investment cash flow sensitivity with tangibility following Almeida and Campello (2007).

$$
\begin{aligned}
I_{i t} & =\beta_{0}+\beta_{1} \text { Cash flow } \text { flt }+\beta_{2}(\text { Cash flow } \times \text { Efficiency })_{i t}+\beta_{3}(\text { Cash flow } \times \text { Tang })_{i t} \\
& +\beta_{4} \text { Fin. slack }_{i t}+\beta_{5} \text { Tobin's }^{\prime} Q_{i t}+\beta_{6} \text { Efficiency } \text { fit }+\beta_{7} \text { Tang }_{i t}+f_{i}+\tau_{t}+\nu_{i t}
\end{aligned}
$$

Therefore, our interpretation does not depend only on a single comparison of the level of estimated cash flow coefficients between two groups of firms, but on multiple comparison of the coefficients of financial slack and two interaction terms as well.

\subsection{Selection equation}

The selection equation places a firm year observation in one of the more or less financially constrained regimes and the likelihood is endogenously determined in each period by multiple firm characteristics that proxy for the severity of informational and agency problems. This 
equation also allows the assessment of the statistical and economic significance of a given factor, while controlling for the information contained in other variables. We include the traditional criteria such as firms' size, age, dividend payout ratio and a set of balance sheet variables as an indicator of financial strength to form our selection vector $Z_{i t}$ in equation 3. We also include our predicted corporate efficiency index and tangibility in the selection vector in order to check how a firm's credit status changes with these two variables. As the general macroeconomic conditions are the same for all firms in the economy or in a particular sector, their effects on the probability of facing any particular regime are expected to be same for all firms as well. Probably due to this same reason Hovakimian and Titman (2006) and Almeida and Campello (2007) do not include time and firm/industry dummies in their selection equations. We use the following selection equation in both model 1 and model 2 irrespective of the specification of the investment equation.

$$
\begin{aligned}
& y_{i t}^{*}=\alpha_{0}+\alpha_{1} \text { Size }_{i t}+\alpha_{2} \text { Age }_{i t}+\alpha_{3} \text { Dividend }_{i t}+\alpha_{4} \text { St. leverage } \text { le }_{i t}+\alpha_{5} \text { Lt. leverage } \text { lev }_{i} \\
& +\alpha_{6} \text { Tobin's }_{i t}+\alpha_{7} \text { Fin. slack }{ }_{i t}+\alpha_{8} \text { Int.cov.ratio }{ }_{i t}+\alpha_{9} \text { Efficiency } \text { fit }+\alpha_{10} \text { Tang }_{i t}+\epsilon_{i t}
\end{aligned}
$$

\section{Data}

We have collected data from the Worldscope Database currently owned by Thomson Reuters which describes the database as the financial industry's premier resource of most comprehensive and accurate financial data on public companies resided outside of the United States of America. ${ }^{3}$ We excluded all banks, life and non-life insurance, real estate, general financial, equity and non-equity investment instrument companies according to the FTSE/Dow Jones Industrial Classification Benchmark (ICB) codes which are adopted by the database as its standard global classification tool codes as they follow different accounting practices. We also dropped all the observations with unexpected signs, like negative revenue, assets or investment and all the other observations with missing values for the required variables. Then we deleted all the firms with less than three consecutive years of

\footnotetext{
${ }^{3}$ The data definitions and other information about the contents of the Worldscope database are contained in http://extranet.datastream.com/Data/Worldscope/index.htm.
} 
observations for any of the required variables. Some firms operating for relatively longer period still have gaps in their panels, but have multiple three consecutive observations in them. Finally, the dataset we use in our estimations is an unbalanced panel of 1122 firms from thirty three different sectors with a minimum of three to a maximum of twenty nine consecutive years of observations and a total of 13183 firm-years. As we allow both entry and exit of firms over time, our estimations using this unbalanced panel data are expected to be free from any potential selection and survivor bias. All required financial variables are deflated with the GDP deflator and all regression variables are winsored at the 1\% and $99 \%$ level to omit extreme outliers. The latter rule is expected to eliminate observations reflecting very large mergers, extraordinary firm shocks, coding or severe measurement errors and is applied as a common procedure in the contemporary finance literature, e.g., Hovakimian and Titman (2006). Table 1 reports means and distributional information for all the regression variables we use in this paper. [Table 1 will be inserted here]

Cash flow representing the flow measure of internal liquidity has a mean value of $3.88 \%$, but there are $21 \%$ firm year observations with negative cash flows. On the contrary, the stock measure of internal liquidity has mean value of $15.79 \%$. This stock measure doesn't have any negative observations, but there are firms with no such short term investment. Recent literature suggests eliminating firm years with Tobin's Q in excess of 10 as an attempt to tackle the measurement error problem of investment opportunities (Almeida and Campello, 2007). As the maximum of 12.69 for Tobin's Q in our data is close to the suggested cut-off point, this is expected to minimize the probable measurement problem to some extent. The sample contains unlevered firms as well as highly levered firms if we consider any of the short term or long term debt positions. An average firm is seen to be more dependent on long term debt with mean value of $10.43 \%$ compared to $6.21 \%$ of the short term debt. This divergence between the two sources of external financing is consistent throughout the sample. The flow measure of indebtness, interest coverage ratio has a mean value of $8.38 \%$ and supports the dependency of an average firm on external debt as well. The level of investment of an average firm is $27.88 \%$ with a median value of $20.45 \%$. And finally an average firm in our sample is $74.5 \%$ efficient compared to its best performing peers, predicted from our market value frontier. 


\section{Empirical results}

\subsection{Effect of efficiency on investment cash flow sensitivity}

Model 1 in table 2 gives the maximum likelihood estimation results of our first switching regression model (equations 7 and 9). As explained earlier, the results are composed of three parts. The selection equation presented in table 2.a which determines a firm's likelihood of being in a constrained or unconstrained regime and two separate investment equations for constrained and unconstrained groups presented in table 2.b which demonstrates how firm investment behavior differs across the two groups. A positive coefficient of any selection variable indicates that firms with higher values of that particular variable are more likely to be in the unconstrained regime or a firm's likelihood of facing financially unconstrained regime is positively related with that selection variable. The relationship will be reversed for any selection variable having a negative coefficient. The reported p-values test the null hypothesis that a single investment regime is sufficient to describe the data as opposed to two regimes.

The results support the general consensus that larger, older and high dividend paying firms are more likely to be in the financially unconstrained regime as these firms are less susceptible to the effects of information asymmetries. The negative coefficient for Tobin's Q hints that firms may not be financially constrained when they do not have better investment opportunities. The negative coefficient for financial slack is also as expected since financially constrained firms have an incentive to hold short term liquid assets. Our estimated coefficient for this variable has a positive sign, but is statistically insignificant. Tangible asset's positive effect on firm's credibility to external financiers is also supported by our findings. All the above explanations and subsequent findings are in line with those given in $\mathrm{Hu}$ and Schiantarelli (1998), Hovakimian and Titman (2006) and Almeida and Campello (2007). Our two stock measures of indebtedness, short term and long term leverage and also the corresponding flow measure, and the interest coverage ratio have positive and statistically significant coefficients. These results indicate that firms with a high level of external debt are associated with a lack of financial constraints or are less dependent on internally generated funds probably due to their high debt capacity or reduced agency cost problems. In other words, these firms may find it easier to convince lenders to provide them with external 
credit on the strength of their collaterizable assets and proven track record. Hovakimian and Titman (2006) provide similar intuition for their sample firms in the decade of 1990-91. According to our hypothesis and the theoretical background behind predicted corporate efficiency, a firm's efficiency has a significant effect on the credit status of the firm. The more efficient a particular firm is or the less severe the agency cost problems, the lower is the firm's probability of facing constrained financial status.

Table 2.b represents the results of the regime specific investment equations estimated simultaneously with the selection equation. The investment equations are estimated with sector and year dummies and clustering by company ID to correct the standard errors. The results reveal that the investment behavior is significantly different between the constrained and unconstrained regimes. The coefficients of Tobin's Q are positive in the two regimes as firms having better investment opportunities are expected to invest more. Investment is positively and significantly related to cash flow and the stock of cash in both the regimes, but as expected the magnitudes of the estimated coefficients for these two variables are larger in the constrained regime than those in the unconstrained regime. This clearly implies that financially constrained firms' investment is more sensitive to internal liquidity due to the difficultly of easily switching between internal and external finance. Most interestingly, investment cash flow sensitivity for financially constrained firms is found to be decreasing with corporate efficiency as opposed to increasing in the unconstrained regime. Such contrasting behavior between the two groups of firms may be explicated by the cost and revenue effect suggested by Cleary et al. (2007). This along with the perceived effect of efficiency on firms' credit status suggest important implication. [Table 2 will be inserted here]

Firms are financially constrained at low level of efficiency, but their investment becomes less and less sensitive to the availability of internal funds as their level of corporate efficiency increases. Higher efficiency makes the agency conflict less severe and enables the firms' managers to take optimal financing and investment decisions, potentially earning higher revenue for these firms. This may switch on the "revenue effect" as higher revenue is expected to lower the firms' default risk subsequently. Therefore, the hindrance to constrained firms' access to external financing source may become less acute with improvement in their efficiency making them less intensely dependent on internally generated funds. This is consistent with 
the findings of Agca and Mozumdar (2008), Attig et al. (2012) and Bond and Söderbom (2013). Once these firms' efficiency reaches a certain standard, they may become financially unconstrained. These unconstrained firms may have high levels of internal funds, but this may still be insufficient to finance all of their investment requirements. This may require higher borrowing, higher repayment costs and consequently bring in a higher risk of default. This "cost effect" may be responsible for their investment becoming increasingly sensitive to cash flow as efficiency increases further. However, we should not be concerned about this positive effect of efficiency on their investment cash flow sensitivity considering that they are not likely to be financially constrained, either internally or externally and they are likely to have the privilege to choose the right mix of internal and external financing.

Overall, our findings indicate a non monotonic effect of corporate efficiency on cash flow sensitivities. At lower level of efficiency, firms are financially constrained and their investment cash flow sensitivity decreases with efficiency. When efficiency reaches a certain threshold, the firms switch from constrained to unconstrained status and their investment cash flow sensitivity starts to increase with efficiency. This is in line with our prediction that the financial constraint status may be endogenously related to the corporate efficiency of the firms. To be specific, the relationship between investment cash flow sensitivity and corporate efficiency may be $U$ shaped as shown in figure 2. The level of efficiency where the status changes from constrained to unconstrained can not be observed, but as explained earlier, our main interest lies on the left part of the figure where efficiency drives down the comparatively high investment cash flow sensitivity for the financially constrained firms and eventually makes them financially unconstrained. Similar to the findings of Agca and Mozumdar (2008), our results support the idea that higher sensitivity of investments to cash flow for the financially constrained firms shouldn't be decreasing with improvement in efficiency if that is solely generated because of the measurement error issue. This implies that cash flow may still claim its role in seizing the effects of capital market imperfections, at least for the financially constrained firms. [Fig 2 will be inserted here] 


\subsection{Credit multiplier effect}

Model 2 of table 2 gives the maximum likelihood estimation results of our second switching regression model (equation 8 along with equation 9). Results of the selection equation of model 2 in table 2.a are almost identical to that of model 1. Firms that are larger, older, have lower market-to-book ratio, have lower financial slack, pay high dividends, more efficient and have more tangible assets are more likely to operate in the unconstrained regime. Highly levered firms' possibility of facing unconstrained credit status remains valid in this model as well. The findings of the two investment equations of our second model in table 2.b are also consistent with those of model 1. Firms operating in the constrained investment regime demonstrate higher sensitivity to our two measures of internal liquidity. The changing credit status of firms with efficiency is also present here. Most importantly, the constrained firms' investment cash flow sensitivity decreases with efficiency in this extended model specification as well. However, the increase in the investment cash flow sensitivity with efficiency for the unconstrained firms is not found statistically significant.

In this model, the additional variables included in the investment equations are tangibility and its interaction terms with cash flow following Almeida and Campello (2007)'s approach. Making use of the Kiyotaki and Moore (1997) credit multiplier model, they find that asset tangibility amplifies the effect of exogenous income shock on the investment spending of financially constrained firms only and raises their investment-cash flow sensitivity. According to them, these firms are better able to increase their collateral value by investing more in pledgable assets following a positive income shock which in turn allows them to raise more external financing, which in turn allows for more investment, and so on. However, at some point these firms become unconstrained and tangibility should no longer affect their investment-cash flow sensitivity. We find a positive and significant effect of tangibility on the investment cash flow sensitivity for both the groups. Not only that, our estimated coefficients suggest that the credit multiplier mechanism is stronger for the unconstrained firms in our sample who are also likely to have high tangible assets. It may be argued here that such positive relation between cash flow and external financing should be particularly strong for those firms with high tangible assets as new investment in more collateralizable assets may enhance their credit capacity more than what is observed for firms with less tangible assets 
(Almeida and Campello, 2010). Hence, our resulting relationship between tangibility and investment cash flow sensitivity is monotonic in contrast with the previous findings.

\subsection{Robustness check}

We conduct a series of robustness check of our proposed hypothesis and results. Firstly, it could be a matter of concern to create the initial classification variable (dependent variable, $y_{i t}^{*}$ ) of our selection equation 9 using efficiency and at the same time including efficiency as an independent variable in the investment equation. In order to tackle this, we estimate both the models excluding efficiency from the $Z_{i t}$ vectors. The results reported in table 3 are found to be robust to this change in the model specification. Our suggested effect of efficiency on firm's credit status is still sustained by the evident non monotonic relationship between efficiency and investment cash flow sensitivity. [Table 3 will be inserted here]

Following $\mathrm{Hu}$ and Schiantarelli (1998), we also include the sales-to-capital ratio as an additional regressor in our investment equations to reduce the possible role of cash flow as a predictor of firm's future profit prospects and to capture possible effects of imperfect competition in the output market. We do the same for our two models and the results are reported in table 4. As expected, magnitude of the estimated cash flow coefficient declines for both the constrained and unconstrained regimes which may be due to the correlation between cash flow and sales. However, the pattern of the cash flow coefficients across the two regimes remains the same as in the models without sales. Investment continues to show higher sensitivity to our two internal liquidity measures for the constrained firms and also the variation of the investment cash flow sensitivity with efficiency and tangibility and their divergence between the two regimes persists. [Table 4 will be inserted here]

The models estimated so far include all contemporary variables, both in the selection and the investment equation. The variables like cash flow, financial slack, Tobin's $Q$ in the investment equation may create endogeneity problems. To account for that, we reestimate the two models replacing the contemporary explanatory variables in the investment equation by their one year lagged values keeping variables in the selection equation same as before. In this case, the selection equation still determines whether the contemporary investment belongs to the constrained and unconstrained regime, but that contemporary investment is 
now explained by one year lagged explanatory variables. The outcomes are reported in table 5 and assert the results already obtained. [Table 5 will be inserted here]

We have also experimented with an alternative initial guess required for the switching regression, specifically using either 60 th, 70th or 80th percentile values as the initial cut-off points, but the results are not found to be sensitive to these changes at all. This confirms that the two regimes are indeed endogenously selected by the model, no matter how we create the initial exogenous classification.

\section{Conclusion}

This paper provides a distinctive complement to the existing literature by suggesting new ways to study the impact of capital market imperfections on investment decisions of individual firms. In our effort to confront the major challenges in this line of studies, we have taken up the proposition that corporate efficiency can simultaneously affect a firm's financial constraint status and investment responsiveness to internal financing and have estimated endogenous switching regression models incorporating our predicted corporate efficiencies from the stochastic frontier analysis. Our endogenous and interchangeable firm classification results reveal that financially constrained firms are more likely to be smaller, younger, deficient in capturing better investment opportunity, reserve higher safety stock, pay low dividends, have less collaterizable assets, less external debt and most importantly, are inferior in terms of corporate efficiency. Turning to their investment behavior, they are comparatively more sensitive to the availability of both the stock and flow measure of internal liquidity pertaining to the idea of imperfect substitutability between internal and external financing source under market imperfections. The much controversial role of cash flow in detecting such imperfections is also given a critical resolution by the decreasing investment cash flow sensitivity with corporate efficiency for these firms. If the mismeasured investment opportunity solely drives the high investment cash flow sensitivity, then it shouldn't be decreasing with improvement of efficiency. Our direct measure of corporate efficiency as an inverse proxy of the extent of asymmetric information and agency conflict problems, thus plays a convincing role here. Our results also support the credit multiplier theory according to which the investment cash flow sensitivity increases with tangibility for both 
the constrained and unconstrained firms. The important implications of our findings to managers and financiers is that, by improving corporate efficiency or in other words, by mitigating agency conflict, taking optimal operating, financing and investment decisions, borrowers can render signals to the outside investors about the actual status of the firm which will then determine the availability and accessibility of external finance for them. An implication of our findings for researchers is that, cross-sectional variation in the investment sensitivity to internal finance may still be interpreted as a consequence of capital market imperfections. We are also aware of some possible limitations of the empirical results we have presented in this paper. Cash flow, financial slack and Tobin's Q in an investment equation can be endogenous and we have checked the robustness of our results by including these variables as one period lagged form. Even though our results suggest that the sensitivity of investment to the availability of internal funds is not solely driven by measurement error in investment opportunity, we are not claiming that Tobin's Q, as our proxy for such is free from measurement error. Usually, an instrumental variable technique or error correction models are suggested for tackling these problems, but none of those could be incorporated within the switching regression framework. For the same reason, we have not estimated our investment equation in a dynamic form. However, we believe that the advantages of the switching regression model outweigh these disadvantages.

\section{References}

Adelegan, O., Ariyo, A., 2008. Capital market imperfections and corporate investment behavior: A switching regression approach using panel data for Nigerian manufacturing firms. Journal of Money, Investment and Banking 2, 16-38.

Agca, S., Mozumdar, A., 2008. The impact of capital market imperfections on investmentcash flow sensitivity. Journal of Banking and Finance 32 (2), 207-216.

Aggarwal, R., Zong, S., 2006. The cash flow-investment relationship: International evidence of limited access to external finance. Journal of Multinational Financial Management $16(1), 89-104$. 
Allayannis, G., Mozumdar, A., 2004. The impact of negative cash flow and influential observations on investment-cash flow sensitivity estimates. Journal of Banking and Finance $28(5), 901-930$.

Almeida, H., Campello, M., 2007. Financial constraints, asset tangibility, and corporate investment. Review of Financial Studies 20 (5), 1429-1460.

Almeida, H., Campello, M., 2010. Financing frictions and the substitution between internal and external funds. Journal of Financial and Quantitative Analysis 45 (03), 589-622.

Alti, A., 2003. How sensitive is investment to cash flow when financing is frictionless? The Journal of Finance 58 (2), 707-722.

Ascioglu, A., Hegde, S. P., McDermott, J. B., 2008. Information asymmetry and investmentcash flow sensitivity. Journal of Banking and Finance 32 (6), 1036-1048.

Attig, N., Cleary, S., El Ghoul, S., Guedhami, O., 2012. Institutional investment horizon and investment-cash flow sensitivity. Journal of Banking \& Finance 36 (4), 1164-1180.

Audretsch, D. B., Elston, J. A., 2002. Does firm size matter? Evidence on the impact of liquidity constraints on firm investment behavior in Germany. International Journal of Industrial Organization 20 (1), 1-17.

Bernanke, B., Gertler, M., 1989. Agency costs, net worth, and business fluctuations. The American Economic Review 79 (1), 14-31.

Bond, S., Cummins, J., 2001. Noisy share prices and the Q model of investment. Working paper 01/22, Institute of Fiscal Studies.

Bond, S., Elston, J. A., Mairesse, J., Mulkay, B., 2003. Financial factors and investment in Belgium, France, Germany, and the United Kingdom: A comparison using company panel data. The Review of Economics and Statistics 85 (1), 153-165.

Bond, S., Klemm, A., Newton-Smith, R., Syed, M., Vlieghe, G., 2004. The roles of expected profitability, tobin's q and cash flow in econometric models of company investment. Working paper 222, Bank of England. 
Bond, S., Meghir, C., 1994. Dynamic investment models and the firm's financial policy. The Review of Economic Studies, 197-222.

Bond, S., Van Reenen, J., 2007. Microeconometric models of investment and employment. In: Heckman, J. J., Leamer, E. (Eds.), Handbook of econometrics. Vol. 6A. Elsevier, North Holland, Amsterdam, pp. 4417-4498.

Bond, S. R., Söderbom, M., 2013. Conditional investment-cash flow sensitivities and financing constraints. Journal of the European Economic Association 11 (1), 112-136.

Calomiris, C. W., Himmelberg, C. P., Wachtel, P., 1995. Commercial paper, corporate finance, and the business cycle: A microeconomic perspective. Carnegie-Rochester Conference Series on Public Policy 42, 203-250.

Calomiris, C. W., Hubbard, R. G., 1990. Firm heterogeneity, internal finance, and "credit rationing'. The Economic Journal 100 (399), 90-104.

Carpenter, R. E., Guariglia, A., 2008. Cash flow, investment, and investment opportunities: New tests using UK panel data. Journal of Banking and Finance 32 (9), 1894-1906.

Chirinko, R. S., Schaller, H., 1996. Bubbles, fundamentals, and investment: A multiple equation testing strategy. Journal of Monetary Economics 38 (1), 47-76.

Cleary, S., 1999. The relationship between firm investment and financial status. The Journal of Finance 54 (2), 673-692.

Cleary, S., Povel, P., Raith, M., 2007. The U-shaped investment curve: Theory and evidence. The Journal of Financial and Quantitative Analysis 42 (1), 1-39.

Cummins, J., Hassett, K., Oliner, S., 2006. Investment behavior, observable expectations, and internal funds. The American Economic Review 96 (3), 796-810.

Devereux, M., Schiantarelli, F., 1990. Investment, financial factors, and cash flow: Evidence from UK panel data. In: Hubbard, R. (Ed.), Asymmetric Information, Corporate Finance and Investment. University of Chicago Press, Chicago, pp. 279-306. 
Erickson, T., Whited, T. M., 2000. Measurement error and the relationship between investment and "q". The Journal of Political Economy 108 (5), 1027-1057.

Erickson, T., Whited, T. M., 2002. Two-step GMM estimation of the errors-in-variables model using high-order moments. Econometric Theory 18 (03), 776-799.

Fazzari, S. M., Hubbard, R. G., Petersen, B. C., 2000. Investment-cash flow sensitivities are useful: A comment on Kaplan and Zingales. The Quarterly Journal of Economics 115 (2), 695-705.

Fazzari, S. M., Hubbard, R. G., Petersen, B. C., Blinder, A. S., Poterba, J. M., 1988. Financing constraints and corporate investment. Brookings Papers on Economic Activity 1988 (1), 141-206.

Gertler, M., 1992. Financial capacity and output fluctuations in an economy with multiperiod financial relationships. The Review of Economic Studies 59 (3), 455-472.

Gertler, M., Gilchrist, S., 1994. Monetary policy, business cycles, and the behavior of small manufacturing firms. The Quarterly Journal of Economics 109 (2), 309-340.

Gilchrist, S., Himmelberg, C. P., 1995. Evidence on the role of cash flow for investment. Journal of Monetary Economics 36 (3), 541-572.

Gilchrist, S., Zakrajsek, E., 1995. The importance of credit for macroeconomic activity: Identification through heterogeneity. In: Is Bank lending Important for the Transmission of Monetary Policy. Federal Reserve Bank of Boston Conference Series. pp. 129-173. URL http://EconPapers.repec .org/RePEc:fip:fedbcp:y:1995:p:129-173:n:39

Gomes, J. F., 2001. Financing investment. The American Economic Review 91 (5), 12631285.

Greenwald, B., Stiglitz, J., 1993. Financial market imperfections and business cycles. The Quarterly Journal of Economics 108 (1), 77. 
Guariglia, A., 2008. Internal financial constraints, external financial constraints, and investment choice: Evidence from a panel of UK firms. Journal of Banking and Finance 32 (9), 1795-1809.

Habib, M. A., Ljungqvist, A., 2005. Firm value and managerial incentives: A stochastic frontier approach. The Journal of Business 78 (6), 2053-2093.

Hadlock, C. J., Pierce, J. R., 2010. New evidence on measuring financial constraints: Moving beyond the KZ index. Review of Financial Studies 23 (5), 1909-1940.

Hausman, J. A., Wise, D. A., 1977. Social experimentation, truncated distributions, and efficient estimation. Econometrica 45 (4), 919-938.

Hayashi, F., 1982. Tobin's marginal q and average q: A neoclassical interpretation. Econometrica 50 (1), 213-224.

Hobdari, B., Jones, D. C., Mygind, N., 2009. Capital investment and determinants of financial constraints in Estonia. Economic Systems 33 (4), 344-359.

Hoshi, T., Kashyap, A., Scharfstein, D., 1991. Corporate structure, liquidity, and investment: Evidence from Japanese industrial groups. The Quarterly Journal of Economics 106 (1), $33-60$.

Hovakimian, G., Titman, S., 2006. Corporate investment with financial constraints: Sensitivity of investment to funds from voluntary asset sales. Journal of Money Credit and Banking 38 (2), 357-374.

Hu, X., Schiantarelli, F., 1998. Investment and capital market imperfections: A switching regression approach using US firm panel data. The Review of Economics and Statistics $80(3), 466-479$.

Hubbard, R. G., 1998. Capital-market imperfections and investment. Journal of Economic Literature 36 (1), 193-225.

Hubbard, R. G., Kashyap, A. K., Whited, T. M., 1995. Internal finance and firm investment. Journal of Money, Credit and Banking 27 (3), 683-701. 
Kadapakkam, P. R., Kumar, P. C., Riddick, L. A., 1998. The impact of cash flows and firm size on investment: The international evidence. Journal of Banking and Finance 22 (3), 293-320.

Kaplan, S. N., Zingales, L., 1997. Do investment-cash flow sensitivities provide useful measures of financing constraints? The Quarterly Journal of Economics 112 (1), 169-215.

Kaplan, S. N., Zingales, L., 2000. Investment-cash flow sensitivities are not valid measures of financing constraints. The Quarterly Journal of Economics 115 (2), 707-712.

Kiyotaki, N., Moore, J., 1997. Credit cycles. Journal of Political Economy 105 (2), 211-248.

Lamont, O., Polk, C., Sa-Requejo, J., 2001. Financial constraints and stock returns. Review of Financial Studies 14 (2), 529-554.

Lensink, R., Bo, H., Sterken, E., 2001. Investment, capital market imperfections, and uncertainty: Theory and empirical results. Edward Elgar Pub.

Lyandres, E., 2007. Costly external financing, investment timing, and investment-cash flow sensitivity. Journal of Corporate Finance 13 (5), 959-980.

Modigliani, F., Miller, M. H., 1958. The cost of capital, corporation finance and the theory of investment. The American Economic Review 48 (3), 261-297.

Moyen, N., 2004. Investment-cash flow sensitivities: Constrained versus unconstrained firms. The Journal of Finance 59 (5), 2061-2092.

Musso, P., Schiavo, S., 2008. The impact of financial constraints on firm survival and growth. Journal of Evolutionary Economics 18 (2), 135-149.

Ng, S., Schaller, H., 1996. The risky spread, investment, and monetary policy transmission: Evidence on the role of asymmetric information. The Review of Economics and Statistics 78 (3), 375-383.

Nguyen, G., Swanson, P., 2009. Firm characteristics, relative efficiency, and equity returns. Journal of Financial and Quantitative Analysis 44 (01), 213-236. 
Oliner, S. D., Rudebusch, G. D., 1992. Sources of the financing hierarchy for business investment. The Review of Economics and Statistics 74 (4), 643-654.

Quader, S. M., 2013. Corporate efficiency, financial constraints and the role of internal finance: A study of capital market imperfection. Ph.D. thesis, University of Sheffield, Sheffield, UK, Available at http://etheses.whiterose.ac.uk/3909/.

Schaller, H., 1993. Asymmetric information, liquidity constraints, and Canadian investment. The Canadian Journal of Economics 26 (3), 552-574.

Schiantarelli, F., 1996. Financial constraints and investment: Methodological issues and international evidence. Oxford Review of Economic Policy 12 (2), 70-89.

Shin, H.-H., Kim, Y. H., 2002. Agency costs and efficiency of business capital investment: Evidence from quarterly capital expenditures. Journal of Corporate Finance 8 (2), 139158.

Shin, H.-H., Park, Y. S., 1999. Financing constraints and internal capital markets: Evidence from Korean “chaebols'. Journal of Corporate Finance 5 (2), 169-191.

Tobin, J., 1969. A general equilibrium approach to monetary theory. Journal of Money, Credit and Banking 1 (1), 15-29.

Whited, T., 1992. Debt, liquidity constraints, and corporate investment: Evidence from panel data. Journal of Finance, 1425-1460.

Whited, T. M., Wu, G., 2006. Financial constraints risk. Review of Financial Studies 19 (2), $531-559$. 
Figure 1: Cut off points for the predicted market value efficiency

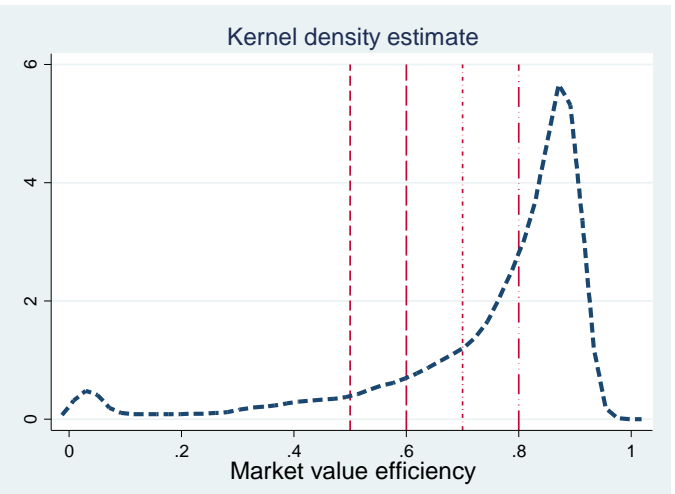

Notes: The kernel density estimation of the predicted market value efficiency shows the negative skewness in its distribution, which is why different cutoff points are used as threshold values for the initial firm classifications.

Figure 2: Non monotonic relationship between investment cash flow sensitivity and efficiency Investment cash flow sensitivity

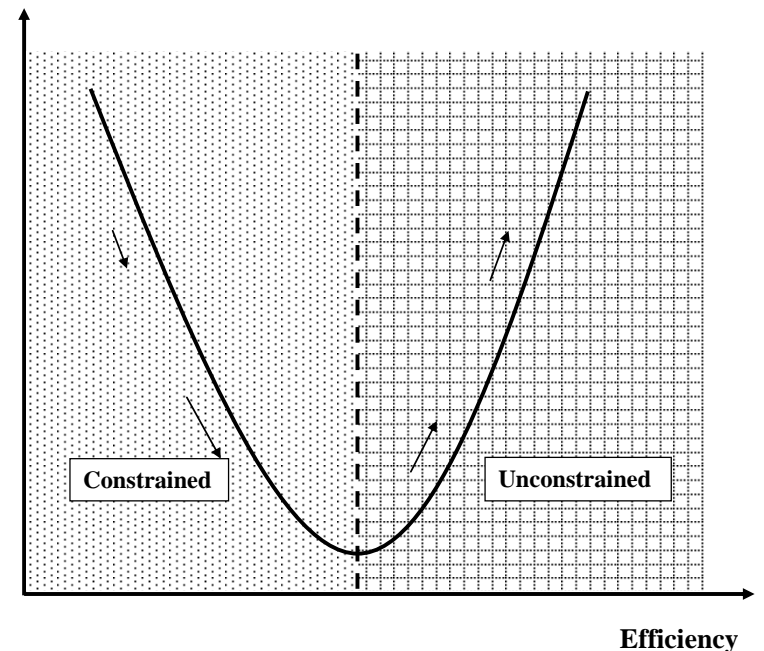

Notes: This figure shows the non monotonic effect of corporate efficiency on the investment cash flow sensitivities of the firms. Investment cash flow sensitivity is found to be decreasing with efficiency for financially constrained firms. Once these firms' efficiency reaches a certain level, they become financially unconstrained and their investment cash flow sensitivity starts increasing. 
Table 1: Descriptive Statistics

\begin{tabular}{lccccccc}
\hline & Mean & SD & Min & Q1 & Median & Q3 & Max \\
\hline Investment & .2787 & .2381 & .0004 & .1194 & .2045 & .3582 & 1.193 \\
Cash flow & .0388 & .2001 & -1.015 & .0198 & .0836 & .1345 & .3385 \\
Tobin's Q & 2.033 & 1.864 & .5193 & 1.072 & 1.464 & 2.178 & 12.69 \\
Tangibility & .2900 & .2386 & .0021 & .0873 & .2453 & .4253 & .9220 \\
Mv.efficiency & .7454 & .2007 & .0056 & .6957 & .8214 & .8760 & 1 \\
Size & 10.92 & 3.243 & 4.301 & 9.448 & 11.28 & 12.97 & 16.74 \\
Age & 2.114 & 0.862 & 0 & 1.609 & 2.303 & 2.833 & 3.367 \\
Dividend & .0207 & .0240 & 0 & 0 & .0157 & .0312 & .1312 \\
St.leverage & .0621 & .0892 & 0 & .0017 & .0281 & .0844 & .4937 \\
Lt.leverage & .1043 & .1352 & 0 & .0003 & .0524 & .1596 & .6539 \\
Fin.slack & .1579 & .1843 & 0 & .0320 & .0936 & .2062 & .8671 \\
Int.cov.ratio & .0838 & .2728 & -1.318 & 0 & .0583 & .1489 & 1.381 \\
\hline
\end{tabular}

Notes: This table gives mean and distributional information for all the regression variables for which data is collected from the Worldscope Global Database for 1122 UK firms listed on the London Stock Exchange over the period 1981 to 2009. All financial variables are deflated with a GDP deflator and all regression variables are winsored at the $1 \%$ and $99 \%$ level to get rid of the extreme outliers. Tobin's Q is calculated as the ratio of market value of assets to the book value of assets. Market value is estimated as book value of total assets minus book value of equity plus market capitalization and book value of total asset is simply the value of total assets. Natural logarithm of total sales and natural logarithm of the number of years a firm appears in the database are used as proxies for firm size and firm age respectively. Financial slack (Fin.slack) is calculated as ratio of cash and short term investment to total assets; cash flow as ratio of funds from operation to total assets; tangibility as ratio of total tangible assets to total assets; interest coverage ratio (Int.cov.ratio) as ratio of interest expense on debt to earnings before interest, taxes and depreciation; dividend payout as ratio of total cash dividend paid to total assets and investment as ratio of capital expenditure or additions to fixed assets to total tangible assets. Short term debt (St.leverage) and long term debt (Lt.leverage) are both scaled by total assets. Market value efficiency (Mv.efficiency) is the corporate efficiency indexes derived from an estimated market value frontier. 
Table 2: Switching regression models with market value efficiency

Table 2.a: Selection equations

\begin{tabular}{lll}
\hline & Model 1 & Model 2 \\
\cline { 2 - 3 } Size & $0.021^{* * *}(0.004)$ & $0.027^{* * *}(0.004)$ \\
Age & $0.449^{* * *}(0.010)$ & $0.465^{* * *}(0.010)$ \\
Dividend & $0.039^{* * *}(0.002)$ & $0.042^{* * *}(0.002)$ \\
St.leverage & $0.768^{* * *}(0.054)$ & $0.497^{* * *}(0.061)$ \\
Lt.leverage & $0.524^{* * *}(0.046)$ & $0.428^{* * *}(0.045)$ \\
Tobin's Q & $-0.055^{* * *}(0.005)$ & $-0.072^{* * *}(0.005)$ \\
Int.cov.ratio & $0.182^{* * *}(0.014)$ & $0.158^{* * *}(0.014)$ \\
Fin.slack & $0.042(0.050)$ & $-0.234^{* * *}(0.049)$ \\
Mv.efficiency & $0.657^{* * *}(0.070)$ & $0.866^{* * *}(0.072)$ \\
Tangibility & $2.452^{* * *}(0.024)$ & $1.304^{* * *}(0.025)$ \\
Constant & $-1.344^{* * *}(0.042)$ & $-1.232^{* * *}(0.043)$ \\
Model p-values & 0.000 & 0.000 \\
\hline
\end{tabular}

Table 2.b: Investment equations

\begin{tabular}{|c|c|c|c|c|}
\hline \multirow[b]{3}{*}{ Cash flow } & \multicolumn{2}{|c|}{ Model 1} & \multicolumn{2}{|c|}{ Model 2} \\
\hline & Unconst. & Const. & Unconst. & Const. \\
\hline & $\begin{array}{l}0.078^{* *} \\
(0.037)\end{array}$ & $\begin{array}{l}0.232^{* * *} \\
(0.059)\end{array}$ & $\begin{array}{l}0.065^{*} \\
(0.037)\end{array}$ & $\begin{array}{l}0.185^{* * *} \\
(0.059)\end{array}$ \\
\hline Cash flow*Mv.efficiency & $\begin{array}{l}0.098^{* *} \\
(0.049)\end{array}$ & $\begin{array}{l}-0.301^{* * *} \\
(0.083)\end{array}$ & $\begin{array}{l}0.031 \\
(0.050)\end{array}$ & $\begin{array}{l}-0.270^{* * *} \\
(0.082)\end{array}$ \\
\hline Cash flow*Tangibility & & & $\begin{array}{l}0.383^{* * *} \\
(0.066)\end{array}$ & $\begin{array}{l}0.229^{* *} \\
(0.090)\end{array}$ \\
\hline Fin.slack & $\begin{array}{l}0.121^{* * *} \\
(0.014)\end{array}$ & $\begin{array}{l}0.157^{* * *} \\
(0.023)\end{array}$ & $\begin{array}{l}0.047^{* * *} \\
(0.014)\end{array}$ & $\begin{array}{l}0.060^{* * *} \\
(0.023)\end{array}$ \\
\hline Tobin's Q & $\begin{array}{l}0.019 \text { *** } \\
(0.001)\end{array}$ & $\begin{array}{l}0.030 * * * \\
(0.002)\end{array}$ & $\begin{array}{l}0.017^{* * *} \\
(0.001)\end{array}$ & $\begin{array}{l}0.027 * * * \\
(0.002)\end{array}$ \\
\hline Mv.efficiency & $\begin{array}{l}-0.016 \\
(0.020)\end{array}$ & $\begin{array}{l}-0.474^{* * *} \\
(0.029)\end{array}$ & $\begin{array}{l}-0.011 \\
(0.018)\end{array}$ & $\begin{array}{l}-0.438^{* * *} \\
(0.028)\end{array}$ \\
\hline Tangibility & & & $\begin{array}{l}-0.205^{* * *} \\
(0.012)\end{array}$ & $\begin{array}{l}-0.337^{* * *} \\
(0.030)\end{array}$ \\
\hline Constant & $\begin{array}{l}0.163^{\text {*** }} \\
(0.020)\end{array}$ & $\begin{array}{l}0.559^{* * *} \\
(0.054)\end{array}$ & $\begin{array}{l}0.216^{* * *} \\
(0.019)\end{array}$ & $\begin{array}{l}0.641^{* * *} \\
(0.057)\end{array}$ \\
\hline
\end{tabular}

Notes: This table gives the maximum likelihood estimation results of our two switching regression models (investment equations 7 and 8 along with the selection equation 9). The selection equation in 2.a determines a firm's likelihood of being in a constrained or unconstrained regime dependent variable of which is coded 1 for the unconstrained investment regime and 0 for the constrained one. A positive coefficient of any selection variable indicates that firms with higher values of that particular variable are more likely to be in the unconstrained regime and vice versa. P-values of the models reject the null hypothesis that a single investment regime is sufficient to describe the data. Two separate investment equations in $2 . \mathrm{b}$ for each of the models demonstrate how different the firms' investment behavior across the two regimes. The investment equations are estimated with sector and year dummies and clustering by company ID is used to correct the error structure of the estimations. $* * *, * *$ and $*$ indicate significance at the $1 \%, 5 \%$ and $10 \%$, level respectively and standard errors are in parentheses. 
Table 3: Switching regression models excluding efficiency from the selection equation

Table 3.a: Selection equations

\begin{tabular}{lll}
\hline & Model 1 & Model 2 \\
\cline { 2 - 3 } Size & $0.057^{* * *}(0.003)$ & $0.074^{* * *}(0.003)$ \\
Age & $0.439^{* * *}(0.010)$ & $0.454^{* * *}(0.010)$ \\
Dividend & $0.036^{* * *}(0.002)$ & $0.037^{* * *}(0.002)$ \\
St. leverage & $0.799^{* * *}(0.053)$ & $0.531^{* * *}(0.060)$ \\
Lt. leverage & $0.497^{* * *}(0.046)$ & $0.394^{* * *}(0.045)$ \\
Tobin's Q & $-0.034^{* * *}(0.004)$ & $-0.045^{* * *}(0.004)$ \\
Int.cov.ratio & $0.183^{* * *}(0.014)$ & $0.157^{* * *}(0.014)$ \\
Fin.slack & $0.007(0.049)$ & $-0.269^{* * *}(0.049)$ \\
Tangibility & $2.505^{* * *}(0.024)$ & $1.376^{* * *}(0.024)$ \\
Constant & $-1.248^{* * *}(0.037)$ & $-1.112^{* * *}(0.038)$ \\
Model p-values & 0.000 & 0.000 \\
\hline
\end{tabular}

Table 3.b: Investment equations

\begin{tabular}{|c|c|c|c|c|}
\hline & \multicolumn{2}{|c|}{ Model 1} & \multicolumn{2}{|c|}{ Model 2} \\
\hline & Unconst. & Const. & Unconst. & Const. \\
\hline Cash flow & $\begin{array}{l}0.074^{* *} \\
(0.038)\end{array}$ & $\begin{array}{l}0.232^{* * *} \\
(0.059)\end{array}$ & $\begin{array}{l}0.059 \\
(0.037)\end{array}$ & $\begin{array}{l}0.187^{* * *} \\
(0.059)\end{array}$ \\
\hline Cash flow*Mv.efficiency & $\begin{array}{l}0.105^{* *} \\
(0.050)\end{array}$ & $\begin{array}{l}-0.294^{* * * *} \\
(0.083)\end{array}$ & $\begin{array}{l}0.040 \\
(0.050)\end{array}$ & $\begin{array}{l}-0.271^{* * *} \\
(0.082)\end{array}$ \\
\hline Cash flow*Tangibility & & & $\begin{array}{l}0.384^{* * *} \\
(0.066)\end{array}$ & $\begin{array}{l}0.235^{* * *} \\
(0.091)\end{array}$ \\
\hline Fin.slack & $\begin{array}{l}0.119^{* * *} \\
(0.014)\end{array}$ & $\begin{array}{l}0.151^{* * *} \\
(0.023)\end{array}$ & $\begin{array}{l}0.045^{* * *} \\
(0.014)\end{array}$ & $\begin{array}{l}0.056^{* *} \\
(0.024)\end{array}$ \\
\hline Tobin's Q & $\begin{array}{l}0.020 * * * \\
(0.001)\end{array}$ & $\begin{array}{l}0.030^{* * * *} \\
(0.002)\end{array}$ & $\begin{array}{l}0.017^{* * *} \\
(0.001)\end{array}$ & $\begin{array}{l}0.027^{* * *} \\
(0.002)\end{array}$ \\
\hline Mv.efficiency & $\begin{array}{l}-0.020 \\
(0.020)\end{array}$ & $\begin{array}{l}-0.492^{* * * *} \\
(0.029)\end{array}$ & $\begin{array}{l}-0.016 \\
(0.019)\end{array}$ & $\begin{array}{l}-0.460^{* * *} \\
(0.028)\end{array}$ \\
\hline Tangibility & & & $\begin{array}{l}-0.204^{* * *} \\
(0.012)\end{array}$ & $\begin{array}{l}-0.332^{* * *} \\
(0.030)\end{array}$ \\
\hline Constant & $\begin{array}{l}0.167^{* * *} \\
(0.020)\end{array}$ & $\begin{array}{l}0.566^{* * *} \\
(0.054)\end{array}$ & $\begin{array}{l}0.220^{* * * *} \\
(0.020)\end{array}$ & $\begin{array}{l}0.647^{* * *} \\
(0.056)\end{array}$ \\
\hline
\end{tabular}

Notes: This table gives the maximum likelihood estimation results of our two switching regression models. Here, only difference is market value efficiency is excluded from the selection equation to check robustness of our earlier results. Pvalues of the models reject the null hypothesis that a single investment regime is sufficient to describe the data. The investment equations are estimated with sector and year dummies and clustering by company ID is used to correct the error structure of the estimations. $* * *, * *$ and $*$ indicate significance at the $1 \%, 5 \%$ and $10 \%$, level respectively and standard errors are in parentheses. 
Table 4: Switching regression models with sales-to-capital ratio

Table 4.a: Selection equations

\begin{tabular}{lll}
\hline & Model 1 & Model 2 \\
\cline { 2 - 3 } Size & $0.039^{* * *}(0.004)$ & $0.035^{* * *}(0.004)$ \\
Age & $0.436^{* * *}(0.010)$ & $0.456^{* * *}(0.010)$ \\
Dividend & $0.050^{* * *}(0.002)$ & $0.046^{* * *}(0.002)$ \\
St. leverage & $0.560^{* * *}(0.065)$ & $0.499^{* * *}(0.064)$ \\
Lt. leverage & $0.405^{* * *}(0.046)$ & $0.376^{* * *(0.045)}$ \\
Tobin's Q & $-0.064^{* * *}(0.005)$ & $-0.067^{* * *}(0.005)$ \\
Int.cov.ratio & $0.158^{* * *}(0.014)$ & $0.148^{* * *}(0.014)$ \\
Fin.slack & $-0.071(0.049)$ & $-0.216^{* * *}(0.049)$ \\
Mv.efficiency & $0.488^{* * *}(0.071)$ & $0.657^{* * *}(0.072)$ \\
Tangibility & $1.602^{* * *}(0.024)$ & $1.142^{* * *}(0.024)$ \\
Constant & $-1.185^{* * *}(0.042)$ & $-1.146^{* * *}(0.042)$ \\
Model p-values & 0.000 & 0.000 \\
\hline
\end{tabular}

Table 4.b: Investment equations

\begin{tabular}{|c|c|c|c|c|}
\hline & \multicolumn{2}{|c|}{ Model 1} & \multicolumn{2}{|c|}{ Model 2} \\
\hline & Unconst. & Const. & Unconst. & Const. \\
\hline Cash flow & $\begin{array}{l}0.052 \\
(0.037)\end{array}$ & $\begin{array}{c}0.146^{* *} \\
(0.058)\end{array}$ & $\begin{array}{l}0.061 \\
(0.037)\end{array}$ & $\begin{array}{l}0.174^{* * *} \\
(0.059)\end{array}$ \\
\hline Sales/Capital & $\begin{array}{l}0.002^{* * *} \\
(0.0001)\end{array}$ & $\begin{array}{l}0.002^{* * *} \\
(0.0001)\end{array}$ & $\begin{array}{l}0.001 * * * \\
(0.0001)\end{array}$ & $\begin{array}{l}0.002^{* * *} \\
(0.0002)\end{array}$ \\
\hline Cash flow*Mv.efficiency & $\begin{array}{l}0.168^{* * *} \\
(0.048)\end{array}$ & $\begin{array}{l}-0.102 \\
(0.082)\end{array}$ & $\begin{array}{l}0.050 \\
(0.050)\end{array}$ & $\begin{array}{l}-0.246^{* * *} \\
(0.082)\end{array}$ \\
\hline Cash flow*Tangibility & & & $\begin{array}{l}0.357^{* * *} \\
(0.063)\end{array}$ & $\begin{array}{l}0.266^{* * *} \\
(0.086)\end{array}$ \\
\hline Fin.slack & $\begin{array}{l}0.106^{* * *} \\
(0.013)\end{array}$ & $\begin{array}{l}0.151^{* * *} \\
(0.022)\end{array}$ & $\begin{array}{l}0.058^{* * *} \\
(0.013)\end{array}$ & $\begin{array}{l}0.088^{* * *} \\
(0.022)\end{array}$ \\
\hline Tobin's Q & $\begin{array}{l}0.017^{* * *} \\
(0.001)\end{array}$ & $\begin{array}{l}0.030^{* * *} \\
(0.002)\end{array}$ & $\begin{array}{l}0.016^{* * *} \\
(0.001)\end{array}$ & $\begin{array}{l}0.030^{* * *} \\
(0.002)\end{array}$ \\
\hline Mv.efficiency & $\begin{array}{l}-0.010 \\
(0.018)\end{array}$ & $\begin{array}{l}-0.543^{* * *} \\
(0.028)\end{array}$ & $\begin{array}{l}-0.011 \\
(0.018)\end{array}$ & $\begin{array}{l}-0.518^{* * *} \\
(0.028)\end{array}$ \\
\hline Tangibility & & & $\begin{array}{l}-0.147^{* * *} \\
(0.013)\end{array}$ & $\begin{array}{l}-0.201^{* * *} \\
(0.030)\end{array}$ \\
\hline Constant & $\begin{array}{l}0.154^{* * *} \\
(0.019)\end{array}$ & $\begin{array}{l}0.598^{* * *} \\
(0.061)\end{array}$ & $\begin{array}{l}0.197^{* * *} \\
(0.019)\end{array}$ & $\begin{array}{l}0.636^{\text {*** }} \\
(0.061)\end{array}$ \\
\hline
\end{tabular}

Notes: This table gives the maximum likelihood estimation results of our two switching regression models. Here, only difference is sales-to-capital ratio is added to the investment equations to check robustness of our earlier results. P-values of the models reject the null hypothesis that a single investment regime is sufficient to describe the data. The investment equations are estimated with sector and year dummies and clustering by company ID is used to correct the error structure of the estimations. $* * *, * *$ and $*$ indicate significance at the $1 \%, 5 \%$ and $10 \%$, level respectively and standard errors are in parentheses. 
Table 5: Switching regression models controlling for endogeneity

Table 5.a: Selection equations

\begin{tabular}{lll}
\hline & Model 1 & Model 2 \\
\cline { 2 - 3 } Size & $0.031^{* * *}(0.004)$ & $0.0003(0.004)$ \\
Age & $0.437^{* * *}(0.010)$ & $0.461^{* * *}(0.010)$ \\
Dividend & $0.045^{* * *}(0.002)$ & $0.041^{* * *}(0.002)$ \\
St. leverage & $0.489^{* * *}(0.061)$ & $0.472^{* * *(0.063)}$ \\
Lt. leverage & $0.654^{* * *}(0.047)$ & $0.427^{* * *}(0.045)$ \\
Tobin's Q & $-0.108^{* * *}(0.005)$ & $-0.103^{* * *}(0.005)$ \\
Int.cov.ratio & $0.117^{* * *}(0.015)$ & $0.148^{* * *}(0.014)$ \\
Fin.slack & $-0.148^{* * *}(0.051)$ & $-0.008(0.050)$ \\
Mv.Efficiency & $0.995^{* * *}(0.070)$ & $1.449^{* * *}(0.073)$ \\
Tangibility & $2.890^{* * *}(0.024)$ & $1.740^{* * *}(0.023)$ \\
Constant & $-0.955^{* * *}(0.041)$ & $-1.373^{* * *}(0.043)$ \\
Model p-values & 0.000 & 0.000 \\
\hline
\end{tabular}

Table 5.b: Investment equations

\begin{tabular}{|c|c|c|c|c|}
\hline & \multicolumn{2}{|c|}{ Model 1} & \multicolumn{2}{|c|}{ Model 2} \\
\hline & Unconst. & Const. & Unconst. & Const. \\
\hline L.Cash flow & $\begin{array}{l}0.079 * * \\
(0.036)\end{array}$ & $\begin{array}{l}0.226^{* * *} \\
(0.056)\end{array}$ & $\begin{array}{l}0.031 \\
(0.040)\end{array}$ & $\begin{array}{l}0.168^{* * *} \\
(0.055)\end{array}$ \\
\hline L.Cash flow*L.Mv.Efficiency & $\begin{array}{l}0.120^{* *} \\
(0.048)\end{array}$ & $\begin{array}{l}-0.297^{* * *} \\
(0.077)\end{array}$ & $\begin{array}{l}0.083 \\
(0.054)\end{array}$ & $\begin{array}{l}-0.273^{* * *} \\
(0.069)\end{array}$ \\
\hline L.Cash flow*L.Tangibility & & & $\begin{array}{l}0.350^{* * *} \\
(0.070)\end{array}$ & $\begin{array}{l}0.239^{* * *} \\
(0.079)\end{array}$ \\
\hline L.Fin.slack & $\begin{array}{l}0.151^{* * *} \\
(0.014)\end{array}$ & $\begin{array}{l}0.192^{* * *} \\
(0.022)\end{array}$ & $\begin{array}{l}0.071^{* * *} \\
(0.014)\end{array}$ & $\begin{array}{l}0.069^{* *} \\
(0.024)\end{array}$ \\
\hline L.Tobin's Q & $\begin{array}{l}0.019^{* * *} \\
(0.001)\end{array}$ & $\begin{array}{l}0.017^{* * *} \\
(0.002)\end{array}$ & $\begin{array}{l}0.016^{* * *} \\
(0.001)\end{array}$ & $\begin{array}{l}0.015^{* * *} \\
(0.002)\end{array}$ \\
\hline L.Mv.Efficiency & $\begin{array}{l}0.033^{* *} \\
(0.016)\end{array}$ & $\begin{array}{l}-0.276^{* * *} \\
(0.029)\end{array}$ & $\begin{array}{l}0.034^{*} \\
(0.018)\end{array}$ & $\begin{array}{l}-0.219^{* * *} \\
(0.035)\end{array}$ \\
\hline L.Tangibility & & & $\begin{array}{l}-0.222^{* * *} \\
(0.013)\end{array}$ & $\begin{array}{l}-0.377^{* * *} \\
(0.036)\end{array}$ \\
\hline Constant & $\begin{array}{l}0.124^{* * *} \\
(0.018) \\
\end{array}$ & $\begin{array}{l}0.213^{* * *} \\
(0.044) \\
\end{array}$ & $\begin{array}{l}0.187^{* * *} \\
(0.019) \\
\end{array}$ & $\begin{array}{l}0.197^{* * *} \\
(0.047) \\
\end{array}$ \\
\hline
\end{tabular}

